Atomic Weapons Tests Safety Committoe in an Australiawide network of sampling stations. Daily sampling was carried out at 24 stations for the first five months of the year, after which the number of stations was reduced to 11. Monthly sampling, using two methods, was conducted at oight stations throughout the year. A report by R. J. I. Alsop, W. J. Gibbs, J. R. Moroney, D. J. Stevens and Prof. E. W. Titterton presents results for total $\beta$-activity measurement on all these samples (Aust. $J$. Science, 26; May 1964). The measurements were intended to provide information on tropospheric and early strato. spheric fall-out over Australia from high-yield nuclear weapon tests in the atmosphere, carried out by the U.S.S.R. and the United States during 1961 and 1962. The most recent release of fission products into the atmosphere in sufficient quantity to be of significance in considerations of global fall-out occurred in late December 1962. Results reported complement data obtained by the Committee in its extensive and continuing survey of strontium-90 in the Australian environment. All stations exposed 6 in. $\times 12$ in. gummed films continuously for the purpose of providing daily samples for the measurement of total activity. The gummed films were changed every $24 \mathrm{~h}$; the radioactivity measurements were made at a central laboratory. Up to May 31, daily gummed film sampling was carried out at 24 stations. Only 22 of the 3,624 daily samples taken during this period showed activities above the minimum detectable level; even the higher activities were just above the minimum detectable level. The survey showed that levels of total $\beta$-activity in fall-out over Australia throughout 1963, as monitored by the daily and monthly sampling methods, were notably lower than in 1962. Towards the end of 1963 the total activity-levels were approaching those recorded before the resumption of nuclear weapon testing in 1961 . However, nuclear weapon testing during 1961 and 1962 resulted in the injection of substantial quantities of strontium-90 and cæsium-137 into the stratosphere which will contribute to the low levels of these long-lived fission products expected in fall-out over Australia. There were indications during 1962 that some strontium-90 in fallout over Australia at that time was arising from recent nuclear weapon testing. Efforts in the fall-out monitoring programme will now be devoted to the continuing assessment of the levels of these long-lived fission products in the Australian environment.

\section{British Lichen Distribution Maps}

THE British Lichen Society now has a Distribution Maps Scheme to record the distribution of lichens within the British Isles. The Scheme is based on the $10-\mathrm{km}$ square system of the National Grid. A record card listing 154 easily identified lichens, with one side blank for additions, is available for use in the field. Eleven members are mapping individual genera or species for early publication. A large number of species are confined to the Highland Zone of Britain, and many lichens have restricted distributions due to such factors as climate, soil conditions, forest clearance, survival of open communities, atmospheric pollution, etc. Maps showing the precise British distribution of lichens will therefore be of considerable interest, and will help to disentangle the various factors which affect the distribution of particular species. Full details of the Scheme can be obtained from the Society's mapping recorder, Mr. M. R. D. Seaward, Lynwode, Vicarage Avenue, Wrawby, Brigg, Lincolnshire. Details of the British Lichen Society itself can be obtained from the secretary, Mr. J. R. Laundon, Department of Botany, British Museum (Natural History), Cromwell Road, London, S.W.7.

\section{Textile Research in Poland}

THE Politechnika Łódźka has published a further issue of its Scientific Bulletins, details of which were given earlier (Nature, 201, 1171; 1964). Issue No. 11
(1964) of Wlókiennictwo contains contributions from the Department of Mathematics of the Chemical Faculty on statistical analysis, and from the Department of Textile Raw Materials and Metrology on the effects of changes in structure, caused by heat-setting, on the mechanical properties of polyethylene terephthalate fibres during stretching. There are also articles on the causes of irregularity in carded flax sliver, and on the analysis of cotton combing in relation to fibre length distribution.

\section{Wellcome Trust Grant for Neurophysiological Research in Canada}

A GRant of $£ 10,000$ is to be made by the Wellcome Trust in London to Dr. V. C. Abrahams and Dr. E. P. Langworth, Queen's University, Kingston, Ontario. This will enable them to establish the necessary computer and tape system for their research work on the neurophysiology of the brain stem. Dr. Abrahams and Dr. Langworth, both of whom formerly worked at the National Institute of Medical Research, Mill Hill, London, went to Queen's University, in 1963, to establish a Neurophysiological Research Unit. Together they have drawn up plans for joint research with other university departments in a programme of research on communication theory, particularly on organization in the brain stem.

\section{Carlsberg-Wellcome Travelling Research Fellowships}

THE Carlsberg Foundation of Copenhagen and the Wellcome Trust of London have announced that the Carlsberg-Wellcome travelling research followships for the year 1964-65 have been awarded to Mr. Jens Hyldgaard-Jensen, of the University of Copenhagen, and Mr. G. C. Coles, of the University of Cambridgo. Mr. Hyldgaard-Jensen, recently a research scholar at the Royal Veterinary and Agricultural College, Copenhagen, will work at the Rowett Research Institute, Aberdeen, under the guidance of Dr. R. N. B. Kay, on problems of the physiology of feeding in cattle. Mr. G. C. Coles, a postgraduate student in the Department of Zoology at the University of Cambridge, will carry out research under Prof. T. Weis-Fogh at the Zoophysiological Laboratory at the University of Copenhagen.

\section{Announcements}

Prof. F. C. Steward, professor of botany in Cornell University, Ithaca, has been awarded the Stephen Hales Prize of the American Society of Plant Physiologists, for his distinguished work on the salt uptake of plants, the nitrogenous constituents of plant tissues, and plant growth regulators.

A JoINT meeting of the Challenger Society and repre. sentatives from the Marine Laboratories (Development Commissioners' Scheme) will be held at the Freshwater Fisheries Laboratory, Pitlochry, during October 14-15. Further information can be obtained from the Secretary. Challenger Society, National Institute of Oceanography, Wormley, Godalming, Surrey.

A SYMPosium on "Concrete Quality", organized by the Cement and Concrete Association, will be held in London during November 10-12. Further information can be obtained from Dr. R. P. Andrew, Cement and Concrete Association, Wexham Springs, Slough, Bucks.

As international conference on "General Relativity and Gravitation" will be held in London at the beginning of July 1965. The main meetings will be held during July 1-10, but arrangements will be made so that those participants who wish may arrive from June 28 onwards in order to take part in discussions and informal seminars. Further information can be obtained from the chairman of the local organizing committee, Prof. H. Bondi, Department of Mathematics, King's College, Strand, London, W.C.2. 